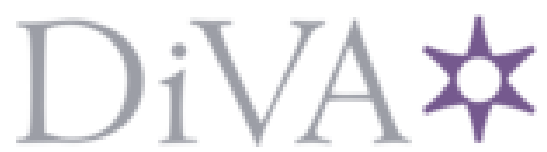

http://www.diva-portal.org

\title{
Postprint
}

This is the accepted version of a paper published in International Journal of Innovation and Sustainable Development. This paper has been peer-reviewed but does not include the final publisher proof-corrections or journal pagination.

Citation for the original published paper (version of record):

Bautista-Puig, N., Elba, M., Elías, S-C. (2021)

Analysis of Social, Environmental and Economic Sustainability Core: A Bibliometric Overview

International Journal of Innovation and Sustainable Development, 15(4): 356-381 https://doi.org/10.1504/IJISD.2020.10026529

Access to the published version may require subscription.

N.B. When citing this work, cite the original published paper.

Permanent link to this version:

http://urn.kb.se/resolve?urn=urn:nbn:se:hig:diva-36921 


\section{Analysis of social, environmental and economic sustainability core: a bibliometric overview}

\section{Núria Bautista-Puig*}

Research Institute for Higher Education and Science (INAECU), University Carlos III of Madrid, Getafe, Madrid, 28903, Spain

and

LEMI (Laboratory on Metric Information Studies),

Department of Library and Information Sciences,

University Carlos III of Madrid,

Getafe, Madrid, 28903, Spain

Email: nbautist@bib.uc3m.es

${ }^{*}$ Corresponding author

\section{Elba Mauleón}

Research Institute for Higher Education and Science (INAECU), University Carlos III of Madrid, Getafe, Madrid, 28903, Spain

Email: elba114@hotmail.com

\section{Elías Sanz Casado}

Research Institute for Higher Education and Science (INAECU), University Carlos III of Madrid, Getafe, Madrid, 28903, Spain

and

LEMI (Laboratory on Metric Information Studies), Department of Library and Information Sciences, University Carlos III of Madrid, Getafe, Madrid, 28903, Spain Email: elias@bib.uc3m.es

Abstract: Sustainability has become a global concern in the 21 st century. However, sustainability is an ambivalent concept that can be interpreted in many ways. In the beginning, it was environmentally-related. Later, however, it was linked to social or economic sustainability, which was known as the 'triple bottom-line' or the 'three-pillar model' (social/economic and environmental sustainability). Later, additional dimensions were incorporated, such as institutional, cultural, or even spatial. As a result of the growth and importance of sustainability, this study provides a comprehensive overview of the core of 
sustainability. With that aim in mind, we will analyse the following aspects of scientific production: volume of scientific output, primary agents involved (countries, institutions), web of science (WoS) categories, collaborations, acknowledgement patterns, and thematic analysis. The findings in this paper suggest an increasing growth in scientific output in all areas of sustainability, albeit with different patterns (e.g., collaboration, specialisation) among the three pillars.

Keywords: environmental sustainability; social sustainability; economic sustainability; sustainability core; bibliometric indicators; sustainability research; research for sustainable development; scientometrics.

Reference to this paper should be made as follows: Bautista-Puig, N., Mauleón, E. and Casado, E.S. (2021) 'Analysis of social, environmental and economic sustainability core: a bibliometric overview', Int. J. Innovation and Sustainable Development, Vol. 15, No. 4, pp.356-381.

Biographical notes: Núria Bautista-Puig is a $\mathrm{PhD}$ candidate in the Research Institute for Higher Education and Science (INAECU) from the University Carlos III of Madrid (Spain). She holds a Degree in Geography from the University of Lleida (Spain) and a Masters in Geographical Information Systems (GIS) and remote sensing. The topic of her $\mathrm{PhD}$ is to analyse the commitment of Higher Education Institutions (HEIs) to sustainability by analysing their scientific output. She had a research stay in prestigious research centers such as Centre for Science and Technology Studies (CWTS) (The Netherlands), Antwerp University (Belgium) and Aveiro University (Portugal) and she has been granted with two early-career prizes (1st Yerun Mobility Award and Early Career Grant for the 14th RDA Plenary). Her areas of expertise include the fields of bibliometrics/scientometrics and technological activity. Moreover, she is involved in the SciShops project, based on citizen science and participatory activities methodologies. She has participated in many national and international conferences and has published peer-review activity for international research journals.

Elba Mauleón holds a $\mathrm{PhD}$ in Library and Information Science from the University Carlos III of Madrid in Spain, after doing her research in the Spanish National Research Council (CSIC). She had three research stays on campuses of international universities of renowned prestige, one in Italy (University of Pisa) and two in the UK (University of Manchester and University of Loughborough). Her research areas of expertise include bibliometric indicators by gender, the infra-representation of women in Science, and Gender Equality and Research Excellence. Her research has led to the opening of new research fronts in bibliometric studies by incorporating the gender perspective in the evaluation analysis of science and technology activity at the macro, meso and micro levels. After getting her $\mathrm{PhD}$, she received a two-year postdoctoral fellowship at the University of Bologna (Italy). All this research has been complemented by presentations in international conferences, co-editing of chapter books, and peer-review activity for international research journals.

Elías Sanz Casado has a PhD in Biological Sciences and a Professor at the Carlos III University of Madrid. He is a Director of the Metrics Information Studies Laboratory (LEMI) and one of the promotors of the Research Institute for Higher Education and Science (INAECU). He has conducted a large number of national and international research projects. He works on different topics: bibliometrics, scientometrics and research evaluation. He has published 
numerous papers in prestigious international journals, in books, book chapters, etc. He has been the supervisor of more than 20 doctoral dissertations. He has participated in many national and international committees for research evaluation.

This paper is a revised and expanded version of a paper entitled 'Analysis of social, environmental and economic sustainability core: a bibliometric overview' presented at VII International Conference on Economic Development and Social Sustainability (Edass 2018), Autonomous University of Madrid (UAM), Madrid, Spain, 17-20 October, 2018.

\section{Introduction}

Humanity has experienced the impact of an unsustainable economic model in all spheres. This global concern and debate started in the 1970s, and the United Nations Conference on the Human Environment (1972) in Stockholm, which was the first conference related to sustainability, has been recognised as the starting point for bringing political attention to environmental problems (Nilsson, 2004). At this inaugural event, the production model was questioned, and 26 principles related to environment and development, as well as an Action Plan, were stated. These recommendations were further elaborated in the World Conservation Strategy (1980) of the International Union for the Conservation of Nature, which advanced sustainable development (SD) by identifying and prioritising conservation and proposing policies (Amador and Oliveira, 2013). In 1983, due to the interest generated by this topic, a World Commission on Environment and Development (WCED) was created, which prepared the document 'Our Common Future' (also known as the Brundtland Report). In this document, SD was defined as a sort of development that meets the needs of the present without compromising the ability of future generations to meet their own needs (Brundtland, 1987). However, some studies have determined that this concept was defined previously by Carls von Carlowitz in a book on sustainable forestry; by Malthus in his book on limits to population growth (Malthus, 1798); in the publication 'Limits to Growth', by the Club of Rome in 1972 (Disterheft et al., 2013); or by the Sustainable Society in 1974 (Lozano, 2008). This term is now globally accepted. However, it has received many critiques for being highly anthropocentric (Waas et al., 2010) and compartmentalised, lacking conceptual coherence, or interconnectedness among all the aspects involved (Lozano, 2008).

This definition of SD from the Brundtland report is also seen as very broad and could have multiple interpretations (Robinson, 2004). Furthermore, it is used as a synonym for sustainability and is commonly interchanged with it (Lozano, 2008). Defining sustainability is also complicated due to the ambivalence of the term (Mitcham, 1995; Holland, 2000). However, there are differences: SD is related more to economic growth as a development strategy that aims to achieve a 'better' type of growth, whereas sustainability is environmentally-related and its main objective is related to humankind, the ability to live within the environmental limits of the planet (Disterheft et al., 2013). Other studies have stated that the main difference lies in the fact that SD is a journey or a path to achieving sustainability (Lozano-Ros, 2003). According to Lozano-Ros (2003), both concepts are a 'change process in which the societies improve their quality of life, reaching dynamic equilibrium between the economic and social aspects, while protecting, 
caring for and improving the natural environment'. The SD change process must have sustainability as its dynamic goal. Originally, sustainability was more environmentallyrelated (Leal Filho, 2000; Sibbel, 2009). Nevertheless, the social and economic dimensions were incorporated as main pillars and are usually incorporated in a triangular concept. The combination of these three pillars was defined as the 'triple bottom line' (TBL) (Elkington, 1998), 'three-pillar model' (Kastenhofer and Rammel, 2005) or the three 'Ps: people, planet, and profits' (Zimmerman, 2005; Sosik, 2011; Sosik and Jung, 2018). Sustainability lies at the intersection between these three pillars. According to this core model (TBL), decision-makers seek strategies to optimise not only environmental, but also social and economic conditions (Wright, 2002). Other studies add other dimensions to the model, such as institutional (Leal Filho et al., 2015), cultural (Axelsson et al., 2013; Leal Filho et al., 2015), spatial (Alshuwaikhat and Abubakar, 2008), or temporal (Zimmerman, 2005; Martens, 2006).

Sustainability and SD have been the core discussion at different summits and conferences. That fact can be interpreted as a growing commitment by countries to work together on the issue. After the Brundtland Report, in 1992, the United Nations Conference on Environment and Development (UNCED), known as the Earth Summit, was held in Rio de Janeiro, Brazil. At this conference, world leaders agreed to 27 principles on environment and development, and an action plan on SD. In 2002, the World Summit on Sustainable Development (WSSD), a 10-year review after Rio, established the Johannesburg Declaration on SD. Although Rio was mostly environmentally-oriented, WSSD incorporated a social and economic aspect (Edwards, 2005), which illustrates the growing interest by the governments of different countries in sustainability. In 2000, the Millennium Summit led to the Millennium Declaration and the creation of the 8 Millennium Development Goals (MDG). These goals were criticised for being inadequately aligned with human rights standards and principles (OHCHR, 2008), and for being relevant only to developing countries (Fukuda-Parr, 2016). Later, in 2012, the Rio + 20 Conference adopted a fifteen-year plan called Agenda 2030 (2015-2030), designed to achieve sustained economic growth, social development, and environmental protection (United Nations, 2016). As a result, it established 17 Sustainable Development Goals (SDGs) indicators in the development agenda on the path to sustainability. These indicators measure the level of achievement in each country, and the High-level Political Forum on Sustainable Development monitors their progress. MDGs and SDGs appeared as a result of the interest and commitment of different countries to sustainable growth.

Sustainability has become a revolutionary movement, to the point of being labelled in some studies as a 'sustainability revolution', and it is happening at different levels (Burns, 2012). Many governments and conferences have highlighted the need to adopt SD principles and to educate people in the direction of a sustainable future. Countries that want to achieve SD must undertake transformations at different levels: education, health, energy systems, land-use, urban development, and many other dimensions. These transformations require long-term changes involving a large number of stakeholders (government, Higher Education Institutions, businesses, civil society) (Bertelsmann Stiftung and SDSN, 2018). All these societal stakeholders are facing this challenge and need to be involved (Brown, 2006).

Higher Education Institutions (HEIs) play a fundamental role, and they should contact agents of change (Hesselbarth and Schaltegger, 2014) in search of solutions. The importance and growing interest in this concept can also be seen in the field of science; 
one of the primary missions of these institutions. The emergence of a new scientific field in the 21 st century called 'sustainability science' (Kates et al., 2001; Kajikawa, 2008) is proof of this interest. Although there is no consensus on its definition, many topics (renewable energy sources, sustainability, etc.) have been analysed from this perspective, and its characteristics have been widely described in literature. Concepts such as transdisciplinarity or being action-oriented are some of them (Kates et al., 2001; Disterheft et al., 2013). Sustainability science researches complex and dynamic interactions between natural and human systems: it aims to bridge the gap between science and society and to limit its knowledge to actions for sustainability (Wiek et al., 2012; Disterheft et al., 2013). On the other hand, scientific databases such as Web of Science (WoS) created a new category in 2016 called 'Green \& Sustainable Science \& Technology', denoting the interest and emergence of a new discipline.

Several studies have analysed sustainability in a scientific field. Bibliometrics, which studies academic publications, has developed tools for examining scientific activity in a given subject area, institution, or country. It can assess the impact and its visibility at different levels (scientific field, journal, or researchers), and it is a powerful way of forming a global picture of research in a particular area. Some scientometric studies have been conducted to analyse scientific production using bibliometric techniques. Pulgarin et al. (2005) analyses sustainable development (SD) research output with 13,093 documents from different countries (Brazil, Spain, and Sweden), while Ramírez et al. (2016) analyses sustainability discourse in the Scopus database. More recent studies analyses sustainability science as a new scientific field (Kajikawa et al., 2014; Nučič, 2012), along with its dynamics, such as patterns of collaboration (Yarime et al., 2010) Some studies focused more on the analysis of scientific production in the area renewable energy sources (Dong et al., 2012; Romo-Fernández et al., 2012; Sanz-Casado et al., 2014), while others focused on sustainability journals (Tang et al., 2018). With regard to the three pillars of sustainability, Fu and Zhang (2017) analyse the trajectory of urban sustainability concepts, Feng et al. (2017) corporate social responsibility, and Ruhanen et al. (2015) sustainable tourism research. As a result, we find that there is very little analysis of the three pillars of sustainability from a bibliometric perspective. Further, in the great majority of these studies, research output and its dynamics (patterns of collaboration, visibility, impact) are analysed. However, acknowledgement patterns as a third edge of the reward triangle (Costas and van Leeuwen, 2012) have been analysed in some fields such as nanotechnology (Wang and Shapira, 2015) or in biomedical disciplines (Álvarez-Bornstein et al., 2019), but not in sustainability research, which constitutes another area of appeal of this paper.

\subsection{Objectives}

Bearing in mind the importance of sustainability, the main objective of this paper is to analyse the trends in sustainability in scientific research; more precisely, the trends related to the core of sustainable development (social, economic, and environmental). The specific objectives are the following:

- to identify the dynamics and agents in this field over time

- to identify the topics of interest

- to analyse any acknowledgement patterns. 
The following research questions are intended to determine the patterns of sustainability in the three areas:

- $R Q 1$. How is core-related sustainability research developed?

- $R Q 2$. What are the main thematic specialisations in these fields?

- $R Q 3$. What are the characteristics of the acknowledgements?

This article is structured as follows: after the Introduction, the Sources and the Methodology are described, followed by the Results and Discussion sections, where the responses to the research questions and the most prominent findings are discussed. Finally, the article ends with the Conclusions.

\section{Sources and methodology}

Within the aforementioned framework, this study provides a comprehensive overview of the core of sustainability. Research was based on publications collected from the WoS database from 1993 to 2017. This international, multi-disciplinary database indexes mainstream scientific publications, providing information used to determine the papers of highest academic prestige in each field. Despite the bias and limitations of this source (Gómez-Caridad and Bordons, 1996), it was chosen because of the high quality of its papers. The publications were retrieved from the Core Collection: science citation index (SCI), Social Sciences Citation Index (SSCI), and Arts and Humanities Citation Index (A\&HCI). Regarding the information on acknowledgements, since August 2008, WoS includes the acknowledgement texts from publications when they mention any funding information.

The procedure was the following:

Formulation of a search strategy. We designed a retrieval search strategy for social, environmental and economic sustainability comprised of the following concepts in title, abstract and keywords (TS field) for the this study applied to the WoS databases Social Sciences Citation Index (SSCI, SSCI-Expanded), Arts \& Humanities Citation Index (A\&HCI) and Proceedings (CPCI-S, CPCI-SSH).

- "economic sustainab*"

- "social sustainab*"

- "environmental sustainab*".

The period of study is limited to the 1993-2017 timeframe. The primary reason for selecting 1993 as a starting point is the fact that there are at least three documents on each one of the pillars. This search strategy retrieved 1683 documents on economic sustainability, 1302 documents on social sustainability and 6107 on environmental sustainability.

Publications were retrieved without regard to the document type and date, and all countries were considered.

- Scientific output retrieval and information processing: the information was retrieved and exported into a relational database created with MySQL. 
- Establishment of bibliometric indicators. The following indicators were analysed:

a Research patterns:

- Yearly variation in scientific output.

- Cumulative average growth rate (CAGR).

- Output by country and institution (absolute values and specialisation index by f-measure (Rousseau, 2018). This specialisation indicator is defined as follows:

$$
f_{\text {measure }}=\frac{2 \times O_{C D}}{O_{D}+O_{C}}
$$

where $O_{C D}$ is the number of publications in a domain (in this case, in the WoS category) in a country in a specific publication window; $O_{D}$ is the number of publications in the world in the domain in the same period, and $O_{C}$ is the number of publications in all domains in the country.

- Collaboration patterns: type (national/international/without collaboration). National collaboration occurs when at least two institutions from the same country collaborate, international collaboration when there are institutions from more than one country, and without collaboration means that there is only one institution.

b Topic specialisation:

- Distribution of output by WoS categories.

- Identification of clusters based on co-occurrence map by keywords (Author Keywords and Plus Keywords), using VOSviewer tool (van Eck and Waltman, 2010).

c Acknowledgement patterns:

- Comparison of output, visibility, and impact of documents with and without acknowledgements.

- Analysis of similarity of the field acknowledgements with IRaMuTeQ software (Camargo and Justo, 2013).

\section{Results}

\subsection{Research patterns}

Concerning research activity patterns, 8765 unique documents on the three pillars of SD were collected during the period (1993-2017). Environmental sustainability has the highest concentration of papers (6107 documents, $69.67 \%$ ), followed by economic (1683 documents, 19.20\%) and social sustainability (1302 documents, 14.85\%). Regarding evolution, the number of documents in each of them shows the growing interest in these issues, with a cumulative average growth rate (CAGR) of $20.48 \%$ in the scientific community, with particular emphasis on environmental research $(21.15 \%)$. During the 
period, research in social and economic aspects has grown by $20.01 \%$ and $19.57 \%$, respectively. Production on this subject is very recent: in the three subfields, more than $54 \%$ is concentrated in the last five years of the study. There were 107 documents on urban sustainability detected since $1996,62 \%$ of them published in the previous five years (Figure 1).

Figure 1 Distribution of publications (1993-2017) on the core of sustainability: economic, environmental, and social (see online version for colours)

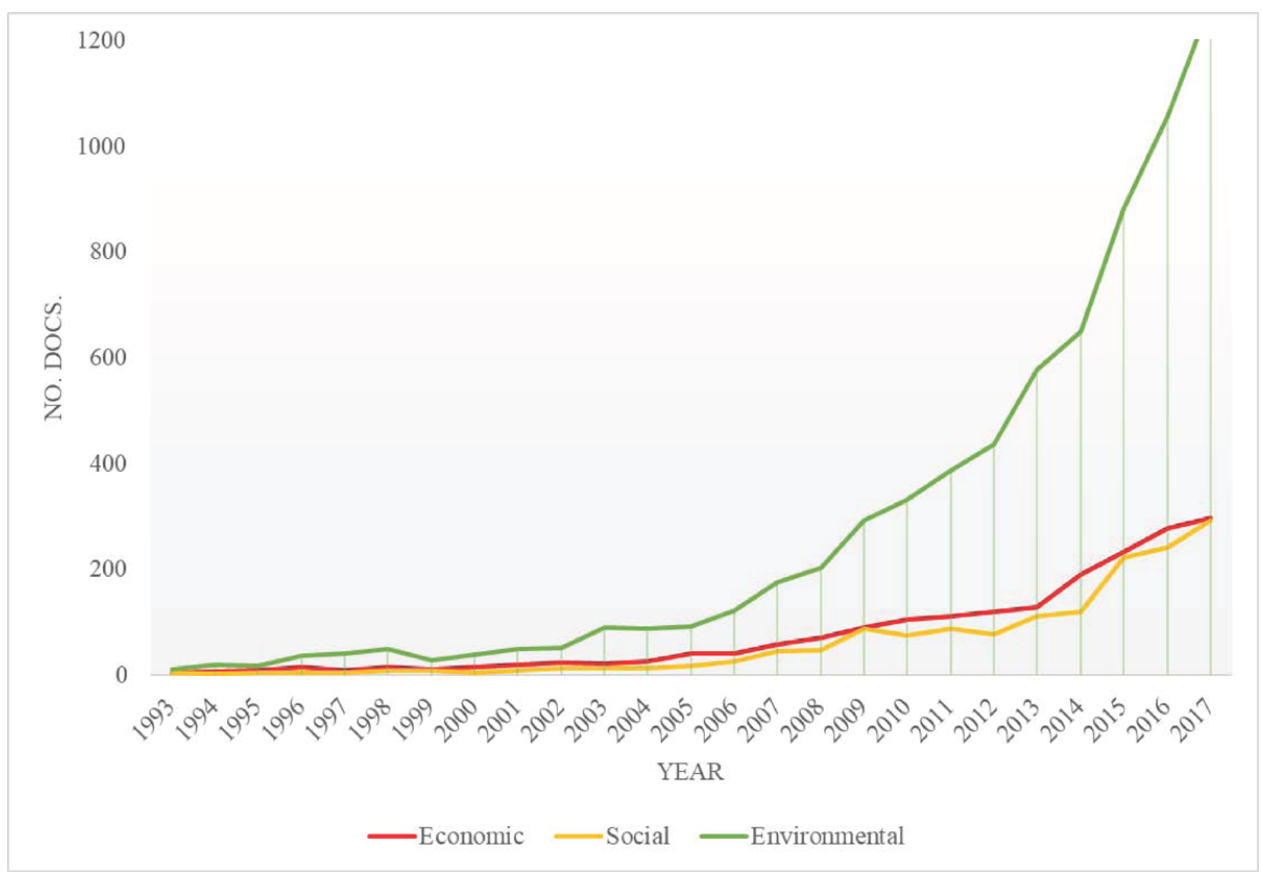

The number of countries involved in scientific research varies by area: 155 countries participated in environmental documents, 107 countries in economic documents, and 83 countries in social documents. As shown in Figure 2, the USA has the highest production in economic sustainability, with 307 documents (18.24\% of the total). However, China, with 263 documents (15.63\%), and Italy, with 207 documents $(12.3 \%)$, have grown significantly over the period analysed. Regarding social sustainability, China, with 203 documents $(16 \%)$, leads the scientific production on this topic, switching the top position with the USA (193 documents, 14.82\%) in the last eight years. The USA, with 1373 documents $(22.5 \%)$, leads the production in environmental sustainability, followed by Italy, with 702 documents (11.49\%), and the UK, with 673 documents (11.02\%).

However, considering the f-measure (Figure 3), which shows specialisation in a specific field, the country distribution offers a different view. Using the f-measure, countries such as Kenya, Indonesia, Romania, or Portugal are the most specialised in economics. In social sustainability, production is specialised most in countries such as Indonesia, Malaysia, Botswana, Kenya, or the Philippines. Finally, regarding environmental sustainability, according to this measure, countries such as Indonesia, Finland, Malaysia, Sweden, Chile, Portugal, Romania, or the Netherlands are the most specialised. 
Figure 2 Publications on sustainability: output by country (1993-2017) (see online version for colours)
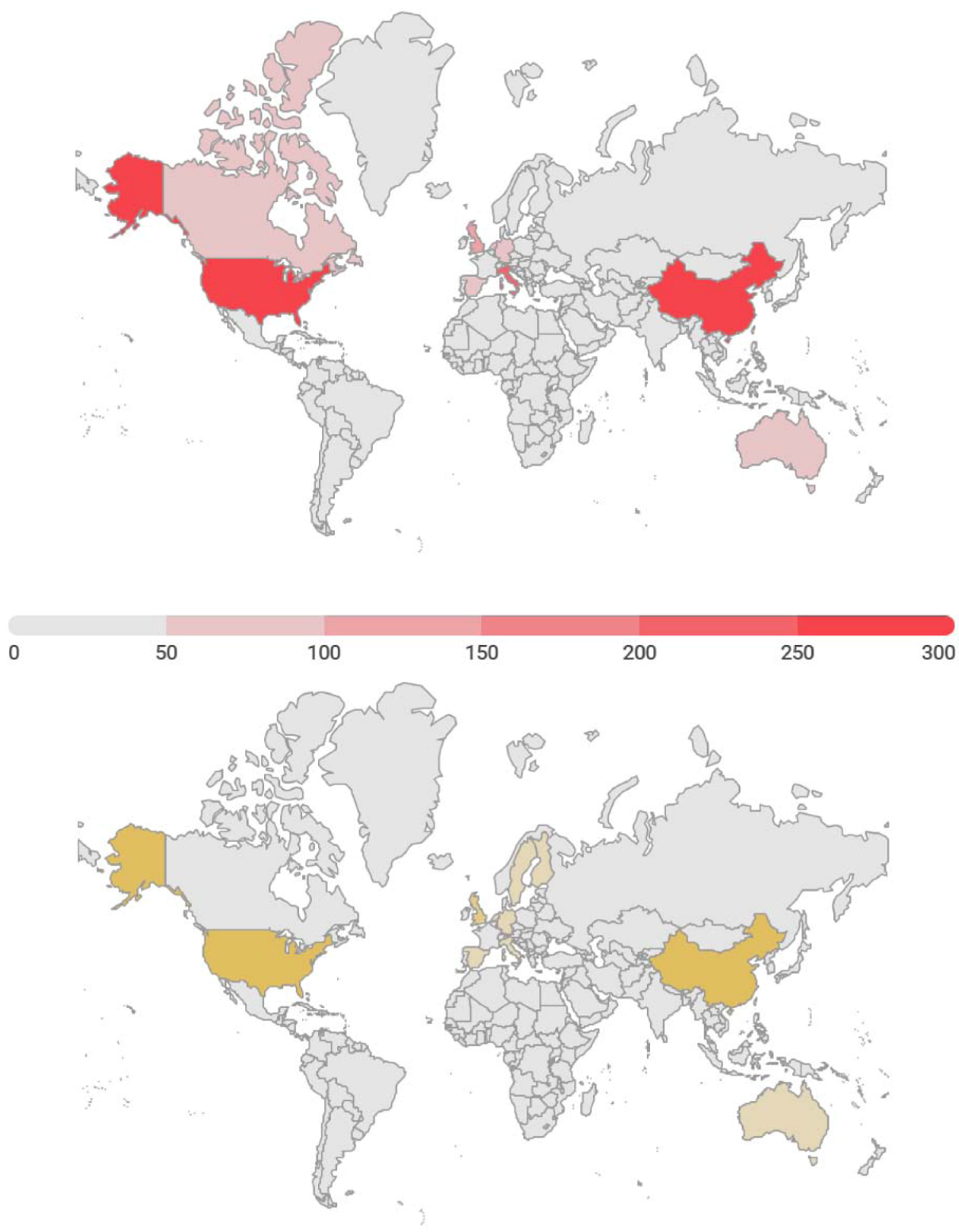
Figure 2 Publications on sustainability: output by country (1993-2017) (see online version for colours) (continued)

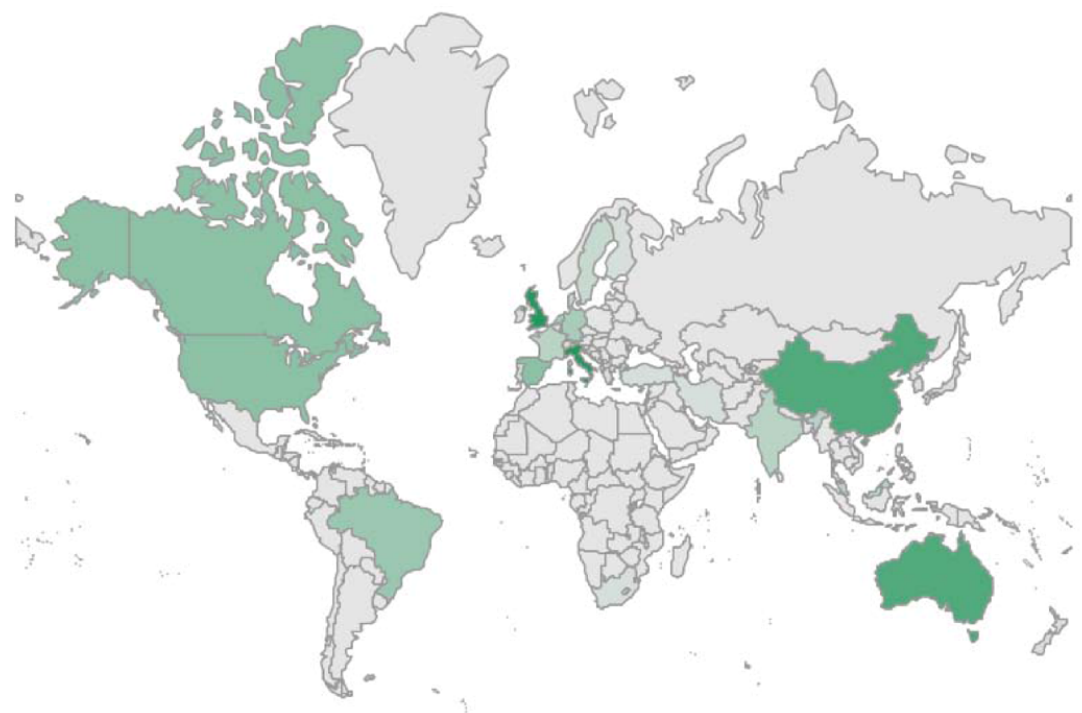

$\begin{array}{lllllllllllllll}0 & 50 & 100 & 150 & 200 & 250 & 300 & 350 & 400 & 450 & 500 & 550 & 600 & 650 & 700\end{array}$

Figure 3 F-measure index by countries (with at least 10 publications) from 1993 to 2017 (see online version for colours)

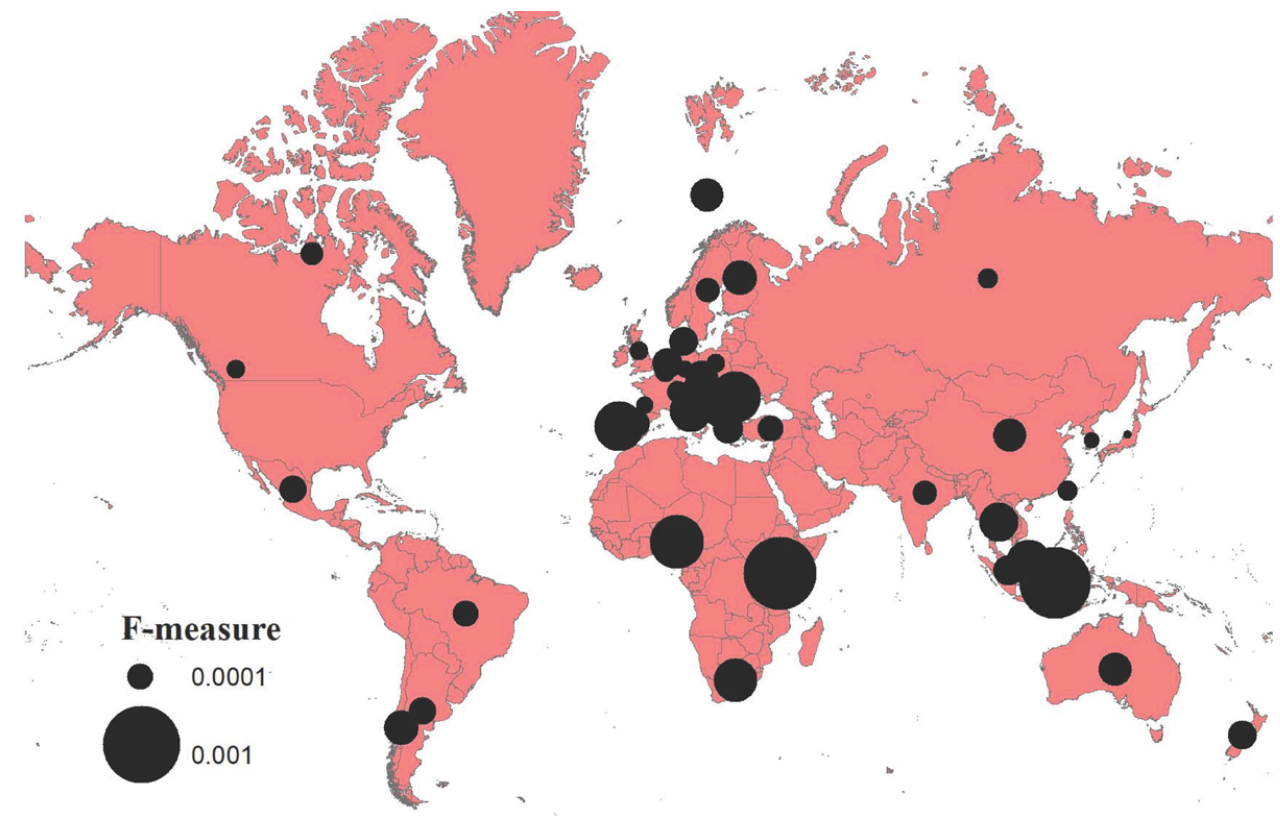


Figure 3 F-measure index by countries (with at least 10 publications) from 1993 to 2017 (see online version for colours) (continued)
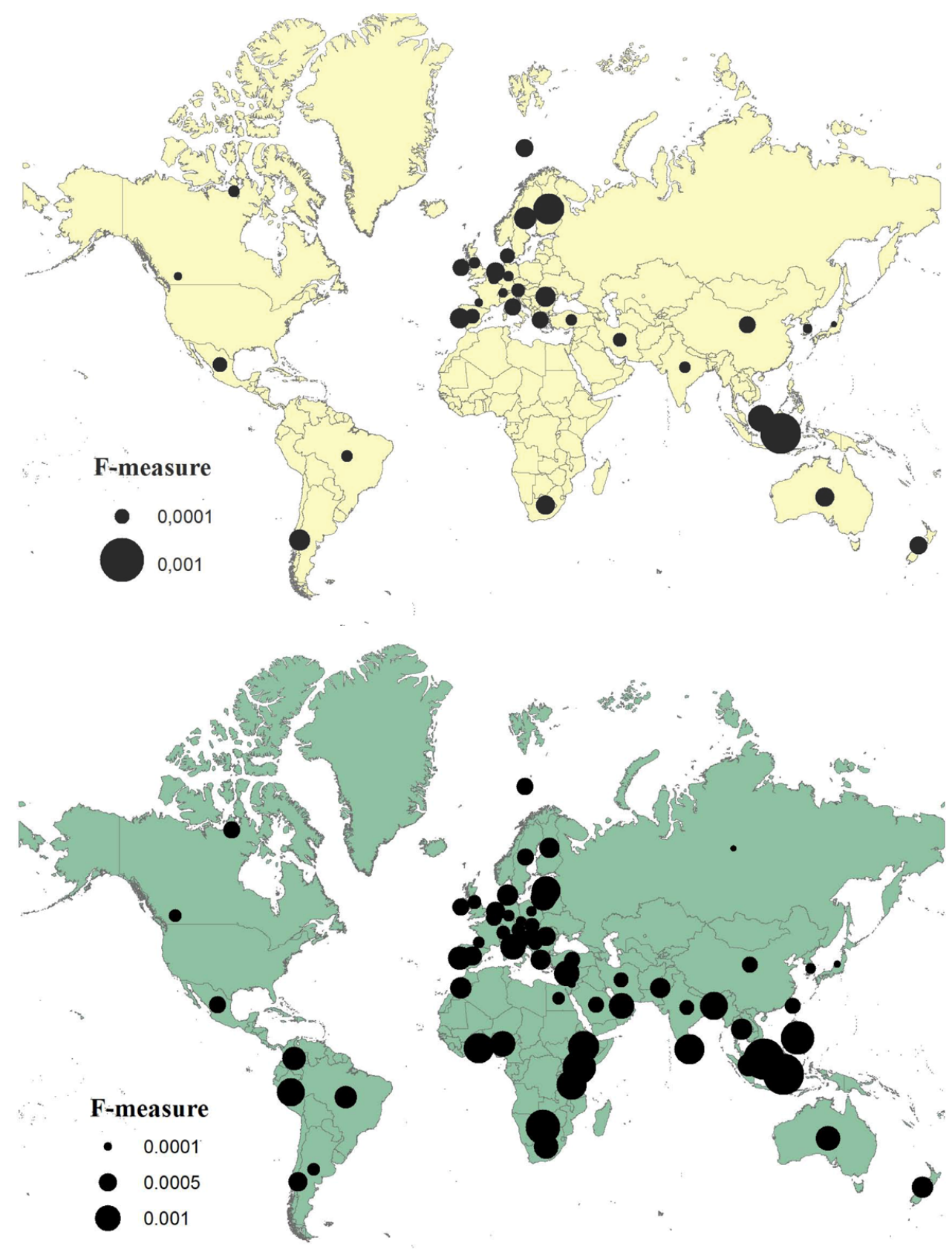

The main agents involved in research are universities, government departments (e.g., United States Department of Agriculture), and research councils (e.g., Chinese Academy of Sciences or Consiglio Nazionale delle Ricerche, CNR). When considering production by pillars of sustainability, it differs: The University of California System is the leading 
producer for environmental sustainability, with 102 documents $(2 \%)$; the Wageningen University Research in the Netherlands, with 25 documents $(2 \%)$, has the highest number of publications in social sustainability; and the Chinese Academy of Sciences, with 33 documents, is the top publisher in the economic field (Table 1). From the results, it is possible to infer that there is no participation by other sectors, such as hospitals or private companies, which would be a very valuable interaction between the public and the private sectors.

Table 1 Top-10 institutions by pillar of sustainability

\begin{tabular}{|c|c|c|c|c|c|}
\hline Economic & & Social & & Environmental & \\
\hline Institution & $\begin{array}{l}\text { No. } \\
\text { docs }\end{array}$ & Institution & $\begin{array}{l}\text { No. } \\
\text { docs }\end{array}$ & Institution & $\begin{array}{l}\text { No. } \\
\text { docs }\end{array}$ \\
\hline $\begin{array}{l}\text { Chinese Academy of } \\
\text { Sciences (China) }\end{array}$ & 33 & $\begin{array}{l}\text { Wageningen University } \\
\text { Research (Netherlands) }\end{array}$ & 25 & $\begin{array}{l}\text { University of California } \\
\text { System (USA) }\end{array}$ & 102 \\
\hline $\begin{array}{l}\text { Wageningen University } \\
\text { Research (Netherlands) }\end{array}$ & 32 & $\begin{array}{l}\text { Aalto University } \\
\text { (Finland) }\end{array}$ & 18 & $\begin{array}{l}\text { Wageningen University } \\
\text { Research (Netherlands) }\end{array}$ & 89 \\
\hline $\begin{array}{l}\text { Consiglio Nazionale delle } \\
\text { Ricerche, CNR (Italy) }\end{array}$ & 24 & $\begin{array}{l}\text { Polytechnic University } \\
\text { of Milan (Italy) }\end{array}$ & 18 & $\begin{array}{l}\text { Chinese Academy of } \\
\text { Sciences (China) }\end{array}$ & 79 \\
\hline $\begin{array}{l}\text { University of California } \\
\text { System (USA) }\end{array}$ & 24 & $\begin{array}{l}\text { Chinese Academy of } \\
\text { Sciences (China) }\end{array}$ & 16 & $\begin{array}{l}\text { State University System } \\
\text { of Florida (USA) }\end{array}$ & 54 \\
\hline $\begin{array}{l}\text { United States Department } \\
\text { of Agriculture (USA) }\end{array}$ & 20 & $\begin{array}{l}\text { Chalmers University of } \\
\text { Technology (Sweden) }\end{array}$ & 15 & $\begin{array}{c}\text { United States } \\
\text { Department of } \\
\text { Agriculture (USA) }\end{array}$ & 51 \\
\hline $\begin{array}{l}\text { State University System } \\
\text { of Florida (USA) }\end{array}$ & 17 & $\begin{array}{l}\text { University of California } \\
\text { System (USA) }\end{array}$ & 15 & $\begin{array}{l}\text { University of London } \\
\text { (UK) }\end{array}$ & 51 \\
\hline $\begin{array}{l}\text { University of Milan } \\
\text { (Italy) }\end{array}$ & 16 & $\begin{array}{l}\text { Aristotle University of } \\
\text { Thessaloniki (Greece) }\end{array}$ & 12 & $\begin{array}{l}\text { Polytechnic University } \\
\text { of Milan (Italy) }\end{array}$ & 51 \\
\hline $\begin{array}{l}\text { Institut National de la } \\
\text { Recherche Agronomique, } \\
\text { INRA (France) }\end{array}$ & 15 & $\begin{array}{l}\text { Delft University of } \\
\text { Technology } \\
\text { (Netherlands) }\end{array}$ & 12 & $\begin{array}{l}\text { Universidade De Sao } \\
\text { Paulo (Brazil) }\end{array}$ & 49 \\
\hline $\begin{array}{l}\text { Polytechnic University of } \\
\text { Milan (Italy) }\end{array}$ & 15 & $\begin{array}{l}\text { University of Helsinki } \\
\text { (Finland) }\end{array}$ & 12 & $\begin{array}{c}\text { University of } \\
\text { Melbourne (Australia) }\end{array}$ & 45 \\
\hline $\begin{array}{l}\text { Pennsylvania } \\
\text { Commonwealth System } \\
\text { of Higher Education } \\
\text { PCSHE (USA) }\end{array}$ & 14 & $\begin{array}{l}\text { University of London } \\
\text { (UK) }\end{array}$ & 12 & $\begin{array}{l}\text { University System of } \\
\text { Georgia (USA) }\end{array}$ & 45 \\
\hline
\end{tabular}

The three types of sustainability show a different profile of citation per document, depending on their area. For that reason, social sustainability documents have the lowest rate of citations ( 0.8 citations/paper). Economic sustainability is the field with the greatest impact (15.35 citations per paper), followed by environmental sustainability (14.81 citations/paper). By using an 8-year period citation window, economic sustainability is the area with the highest citation/paper rate in the 1993-2000 and 2001-2008 periods (33.13 and 42.60 citations/paper, respectively), despite the figures in the environmental area, which is higher than economic sustainability in the latter period (11.91 vs 8.39 citation/paper). 
Patterns of collaboration are different. However, international collaboration has increased in all fields. Environmental sustainability has the highest number of documents with international collaboration (23.62\%), followed by social sustainability $(20.43 \%)$ and economic (18.36\%). If we check the evolution using the cumulative average growth rate (CAGR), environmental sustainability is the area with the highest growth during the period (28.4\%), followed by social (CAGR of 18.68\%) and economic (CAGR of $18.35 \%$ ). However, regarding national collaboration, economic has the highest value (26\%), followed by environmental sustainability, with $24.05 \%$, and social sustainability, with $19.20 \%$. Social is the area in which this collaboration has grown the most during the period (27.5\% CAGR), followed by environmental (20.31\%), and economic (17.76\%) (Table 2 and Figure 4).

\subsection{Topic specialisation}

The three areas focused their production on the WoS category 'Environmental Sciences': $24.46 \%$ in the environmental area, $16.59 \%$ in the social area, and $14.02 \%$ in the economic area. The next two categories are: 'Environmental Studies' (15.31\% social, $12.41 \%$ environmental, $7.55 \%$ economic) and 'Green \& Sustainable Science \& Technology' (13.66\% environmental, $11.83 \%$ social, and $6.89 \%$ economic). Other categories involved in economic sustainability are: 'Energy and Fuels' (6.60\%), 'Economics' (5.17\%), 'Ecology' (4.22\%), or 'Engineering, Environmental' (3.86\%). Regarding social sustainability, some of the WoS categories are: 'Planning and Development' (5.07\%), 'Geography' (4.38\%), or 'Urban Studies' (3.61\%). In last place, environmental sustainability is included in WoS categories such as 'Engineering, environmental' (9.9\%), 'Management' (5.85\%), 'Water resources' (3.96\%), or 'Engineering, civil' (3.83\%) (Figure 5).

Figure 4 Evolution of national collaboration, international collaboration and without collaboration in the three pillars (see online version for colours)

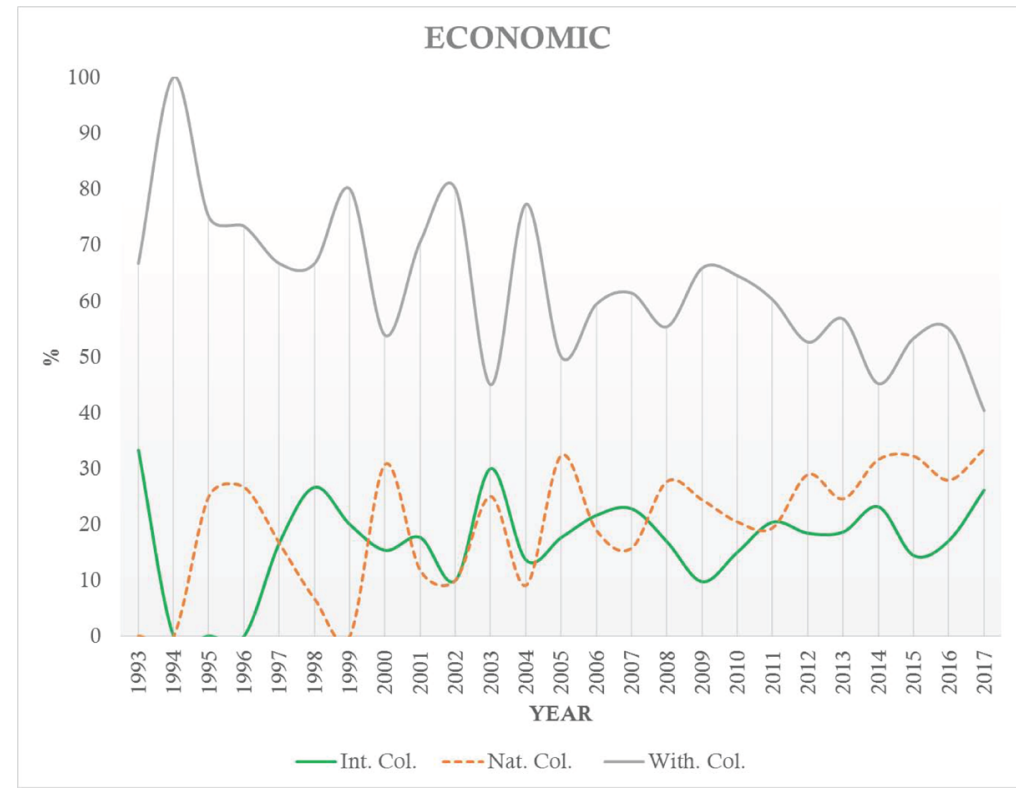


Figure 4 Evolution of national collaboration, international collaboration and without collaboration in the three pillars (see online version for colours) (continued)
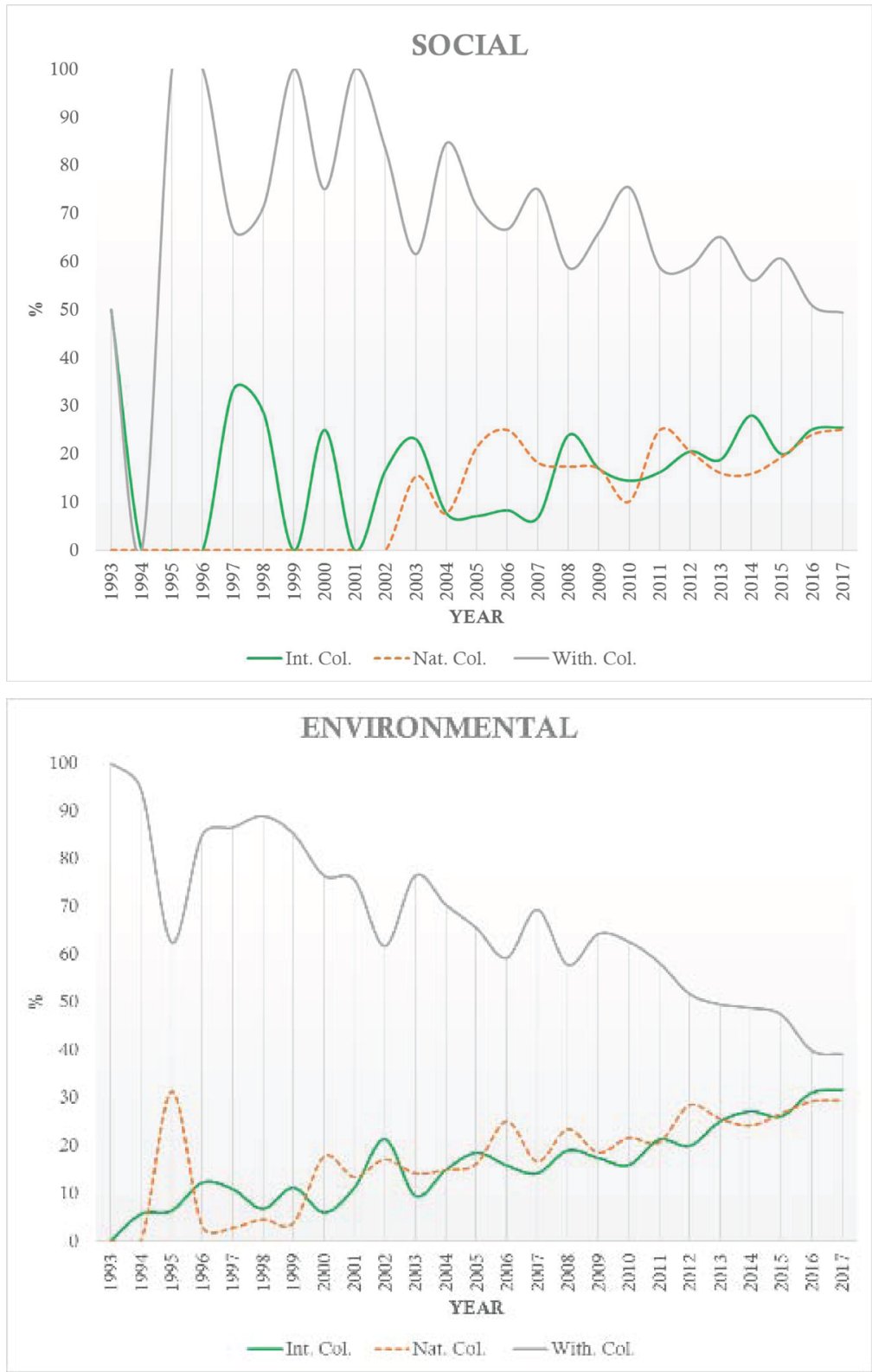

A co-occurrence map based on keywords was drawn to determine the state of research: node size is indicative of the number of documents, whilst the thickness of the lines identifies inter-document relationships and their intensity. In the period analysed (1993-2017), the economic sustainability network identified four clusters. Based on the terms used, Cluster 1 is related to research that seeks to examine the different potential environmental impacts associated with each stage of a product's life cycle and includes 
terms such as 'life-cycle assessment', 'energy', 'impact', or 'biomass', among others. The second cluster is related more to SD and is linked to the other pillars (environmental and social). It includes terms such as 'agriculture', 'policy', and 'innovation', which indicates that economic research of SD is linked to policies on these matters, especially on agriculture. The third cluster deals with management and performance to achieve a more sustainable future. Research in this cluster includes terms such as 'indicators', 'systems', 'performance', or 'impact', and may be related to the evaluation of sustainability with regard to the economy. It also includes terms such as 'China' or 'growth', which denotes that, in economic sustainability, there is a concern over China's growth. A fourth cluster is related to 'conservation', 'biodiversity', 'climate change', and 'governance', and may be associated with the economic view of sustainability. (Figure 6).

Four clusters were detected in the social sustainability network. One of them deals with sustainable development, and its terms seem to be linked to evaluation or impact assessments in this area and how they affect decision-making. It is also connected to environmental aspects (biodiversity, conservation, energy, and water). The second cluster is related to management, and performance and industry appear as a node, indicating the importance of the relationship between industry and sustainability. From a social perspective, there are certain terms, such as 'corporate social responsibility' that indicate a business approach that goes in line with SD by delivering economic, social, and environmental benefits to all stakeholders. The third is related to policy, consumption, environment, and communities. The 'cities' node indicates interest in urban studies. This term is also linked to concepts such as 'density', 'health', or 'governance', which shows concern over the way cities are managed. Finally, the last and smallest cluster is related to 'certification' and, especially, 'construction'. It is also linked to terms such as 'quality' or 'integration' (Figure 7).

There are three main clusters in the environmental sustainability network (Figure 8). The first is related primarily to life-cycle assessment and energy, covering research that seeks to quantify and characterise the different potential environmental impacts. Terms such as 'greenhouse emissions', 'carbon', 'impact', 'efficiency', or 'energy consumption' are examples of this concern. The second cluster deals with performance and management. From an environmental perspective, it includes terms such as 'innovation', 'barriers', or terms that are firm-related ('firm performance', 'competitive advantage', 'operations management', or 'logistics'). This cluster, which is common to all the three pillars, indicates that there is research on how to evaluate the different measures to achieve a sustainable future. The third cluster in the network is related to sustainable development, environment, and climate change. It includes terms such as 'China', 'growth', 'policy', 'education', or 'health' and covers the different topics of sustainable development. This specific cluster is also common to the third pillar, which shows the interest of scientific literature in SD.

Table 2 Number of documents with national collaboration, international collaboration, and without collaboration in the three pillars

\begin{tabular}{lcccccccc}
\hline Economic & No. docs & $\%$ & Social & No. docs & $\%$ & Environmental & No.docs & $\%$ \\
\hline Int. col. & 309 & 18.36 & Int. col. & 266 & 20.43 & Int. col. & 1443 & 23.63 \\
Nat. col. & 437 & 25.97 & Nat. col. & 250 & 19.20 & Nat. col. & 1469 & 24.05 \\
With col. & 903 & 53.65 & With col. & 767 & 58.91 & With col. & 3092 & 50.63 \\
\hline
\end{tabular}


Figure 5 Distribution by WoS categories by economic sustainability (a), social sustainability (b), and environmental sustainability (c) (see online version for colours)

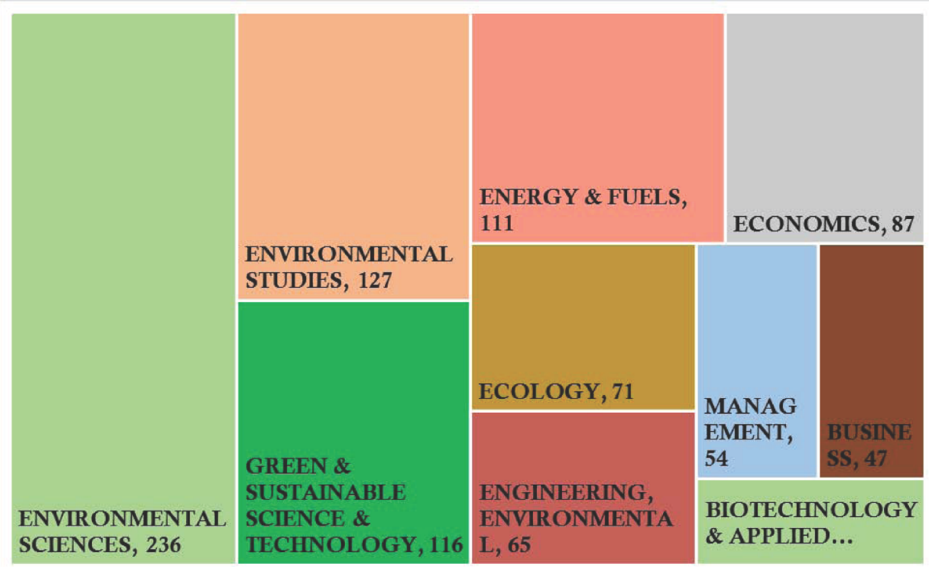

(a)

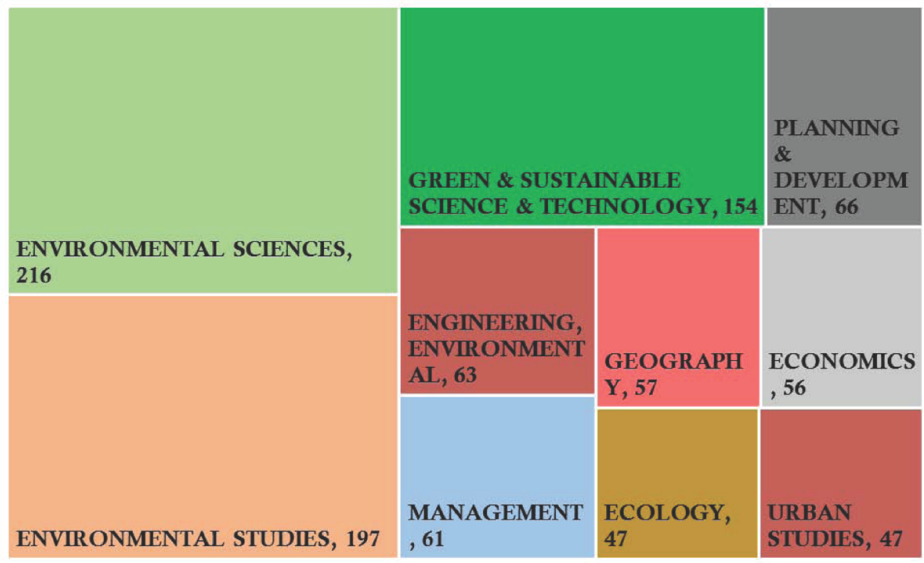

(b)

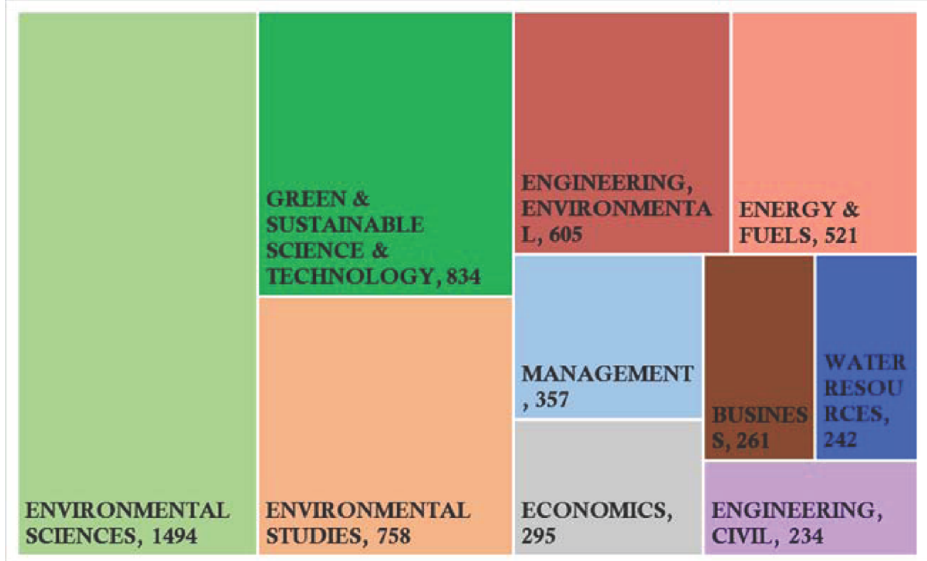

(c) 
Figure 6 Analysis of topics (cooccurrence map by keywords) in economic sustainability ( $<20$ keywords) (see online version for colours)

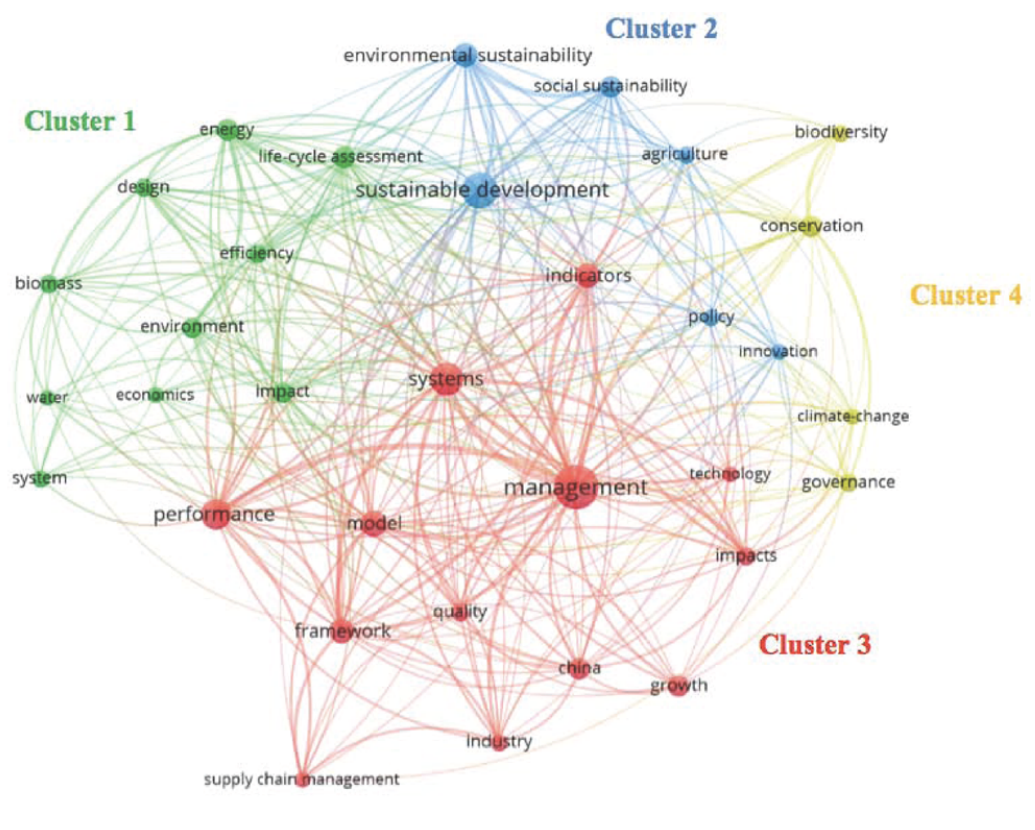

Figure 7 Analysis of topics (cooccurrence map by keywords) in social sustainability $(<15$ terms) (see online version for colours)

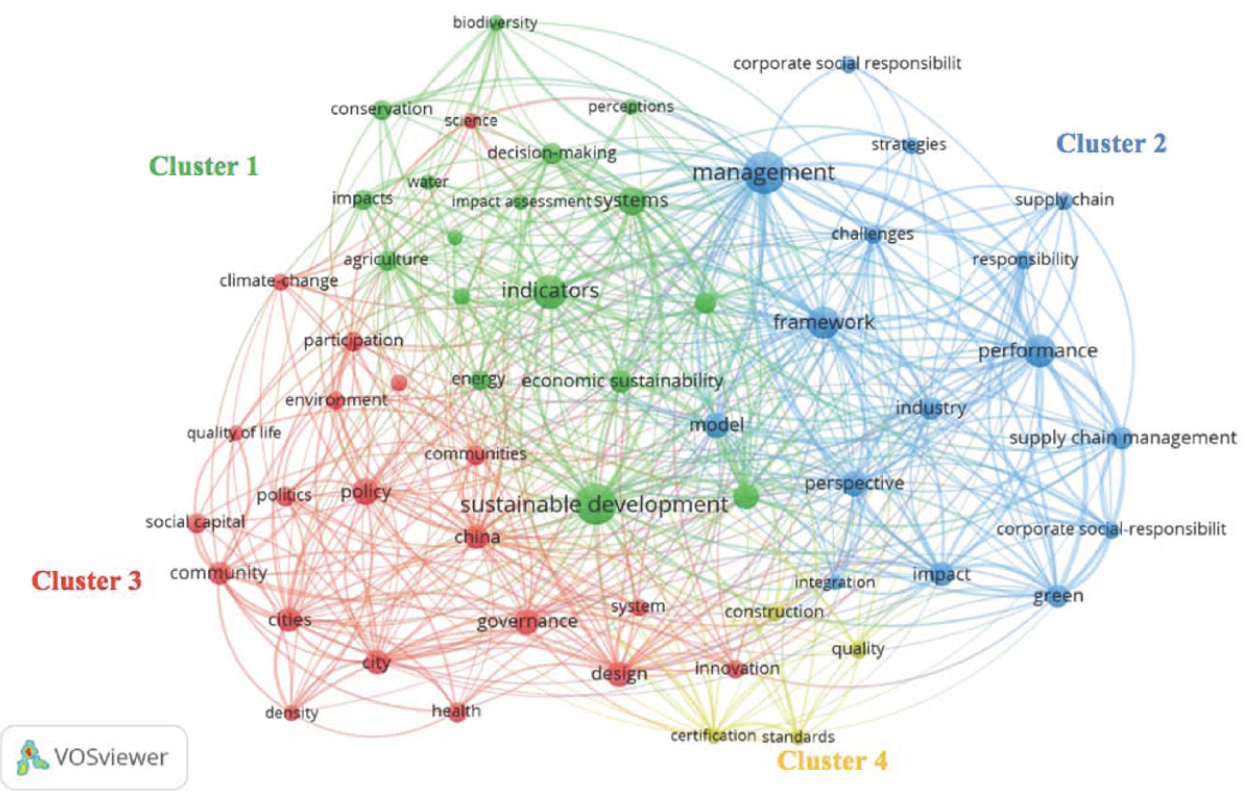




\subsection{Acknowledgement analysis}

Analysing information on acknowledgements in WoS enables us to explore the relationship between funding and research output. Table 3 shows the patterns in the different areas of the sustainability core. The highest number of documents with acknowledgements belongs to environmental sustainability $(32.83 \%)$, whilst economic sustainability has the lowest number of documents with acknowledgements $(29.01 \%)$. Taking into consideration the funding organisations, in environmental sustainability the organisations with the highest number of documents are government institutions (European Commission with 86 documents) or research councils (National Natural Science Foundation of China with 199 documents, Engineering and Physical Sciences Research Council (EPSRC) with 30 documents). In economic sustainability, the funding organisations are councils (Chinese Academy of Sciences with 21 documents or Consiglio Nazionale delle Ricerche (CNR) with 12 documents) and Higher Education Institutions (HEIs)/Research Centres (Wageningen University research with 16 documents or State University System of Florida with 9 documents). Regarding social sustainability, the profile of funding agencies with acknowledgements are councils (National Science Foundation of China with 20 documents) or government organisations (European Commission with 19 documents).

Figure 8 Analysis of topics (cooccurrence map by keywords) in environmental sustainability (see online version for colours)

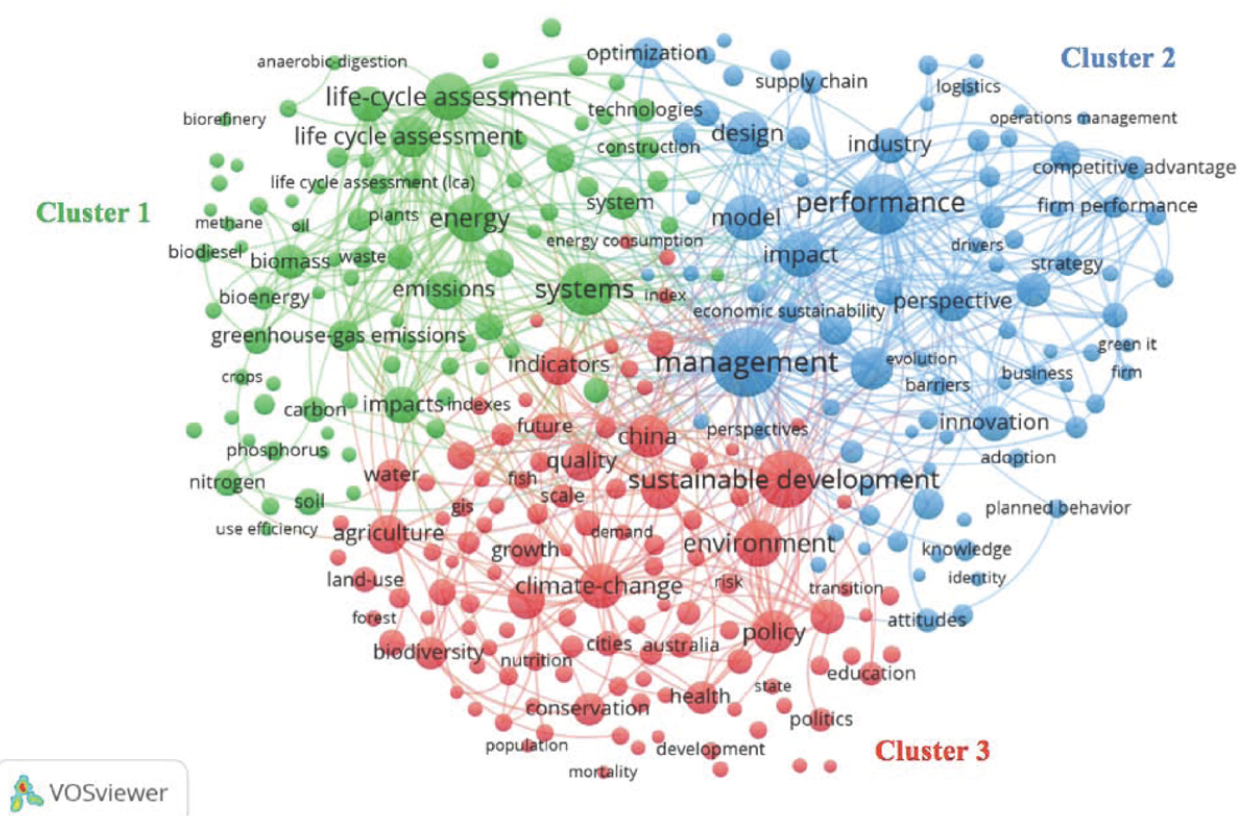

As regards impact, considering the citations/article rate, the impact is higher in documents with funding than in those with no funding in social sustainability $(21.81$ citations/art. vs 11.73 without funding acknowledgements, FA) and environmental sustainability (26.31 citations/art. vs 26.3 citations/art without FA). The impact is higher in the sustainability area, and there is also greater international collaboration. In the area 
of visibility, first-quartile documents (1Q) seem to have a higher percentage in documents without FA. In terms of the size of the teams (number of authors per paper), it is higher in all pillars in documents with funding ( 4.3 authors/doc in economic, 3.35 authors/doc in social, and 4.28 authors/doc in environmental sustainability), which indicates that research in sustainability with funding is conducted by larger teams.

Figure 9 shows an analysis of similarity based on the three pillars in the field 'Acknowledgments', showing how the authors specified their acknowledgment. This approach studies the way authors express their gratitude: terms such as 'research' or 'fund' are related to 'project', 'development', 'program'; 'support' is a term related to the grant that has financed the paper, but other words belonging to this block are 'work', 'acknowledge' or 'science'. Another pattern detected is the way the author expresses thanks for the assistance or the contribution received. Finally, a 'comment' part is linked to the manuscript, the editor, or is related to help received or improvements made to the paper.

Figure 9 Analysis of similarity of the field acknowledgements with IRaMuTeQ software (see online version for colours)

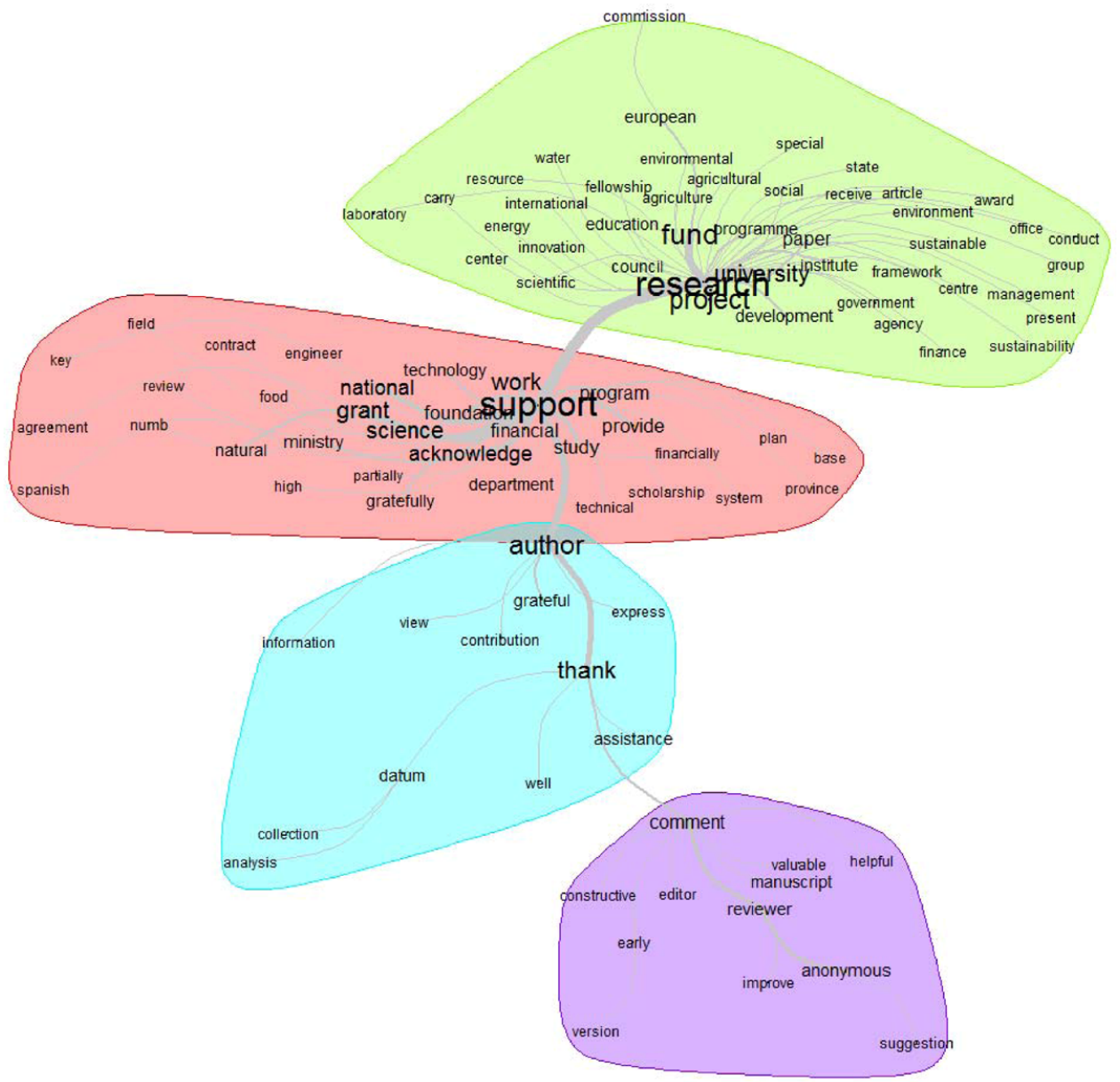


Table 3 Acknowledgement patterns by sustainability area (Economic, social and environmental)

\begin{tabular}{|c|c|c|c|c|c|c|}
\hline & \multicolumn{2}{|c|}{ Economic } & \multicolumn{2}{|c|}{ Social } & \multicolumn{2}{|c|}{ Environmental } \\
\hline & With FA & $\begin{array}{c}\text { Without } \\
\text { FA }\end{array}$ & With FA & $\begin{array}{c}\text { Without } \\
\text { FA }\end{array}$ & With FA & $\begin{array}{c}\text { Without } \\
\text { FA }\end{array}$ \\
\hline No. documents & 489 & 1194 & 338 & 964 & 2005 & 4102 \\
\hline$\%$ & 29.01 & 70.94 & 25.96 & 74.04 & 32.83 & 67.17 \\
\hline \multicolumn{7}{|c|}{ 1Qjournals } \\
\hline$\%$ & 48.01 & 56.03 & 6.30 & 13.98 & 2.80 & 3.72 \\
\hline \multicolumn{7}{|c|}{ Citations } \\
\hline Citations/article & 21.13 & 24.90 & 21.81 & 11.73 & 26.31 & 19.77 \\
\hline \multicolumn{7}{|c|}{ Group size } \\
\hline No. Authors/art. & 4.33 & 2.49 & 3.35 & 2.04 & 4.28 & 2.39 \\
\hline
\end{tabular}

\section{Discussion and conclusions}

Achieving long-term sustainability and SD is a challenge for all countries. Numerous Earth Summits and Conferences have been held during the 21 st century, which is indicative of the interest of global leaders in working together to achieve better growth. In this work, an analysis of research in the triple bottom line approach (TBL) has been conducted to determine whether or not scientific interest is in line with the interest in society.

$R Q 1$. How is core-related sustainability research developed?

Regarding scientific production, 8613 unique documents were collected from WoS for the period of 1993-2017: environmental sustainability is the pillar with the highest number of documents $(n=6107)$. The results of this study suggest that although one could assume that this topic might have a long tradition, the number of documents is concentrated in the most recent years (more than $54 \%$ in the three fields). Research output begins to grow during the 2000s, coinciding with the different Conferences (Millennium Summit 2000, Earth Summit 2002, Rio +20 ) and the development of the MDGs and SDGs. This trend supports the findings of Pulgarín et al. (2005), Nučič (2012) or Kajikawa (2014) regarding SD and sustainability science. Further, according to certain studies (Ramírez Ríos et al., 2016), this growth can be explained by the emergence of the concept of 'sustainable development'. Among the three pillars, the one with the greatest increase over the period (CAGR of $21.15 \%$ ) is environmental sustainability, which shows that research has gained more interest in this pillar. Regarding social sustainability, as pointed out by some studies (Ramírez Ríos et al., 2016), growth can be related to the emergence of urban sustainability studies.

As to the main agents involved, the number of countries in scientific research is higher in environmental science, related to international collaboration, which has a higher percentage (23.63\%). This fact is associated with the study by Yarime et al. (2010), which stated that there is an increasing number of countries engaged in research on sustainability. The results suggest that scientific production is concentrated mainly in 
developed countries. The primary producers are the USA and China for economic sustainability, the USA and China for social sustainability, and the USA and Italy for environmental sustainability. The importance of China in the number of publications is also seen in other studies and can be related to the considerable increase of scientific research funds in recent decades (Tang et al., 2018) and their leadership in the scientific field, as China has become the world's largest producer of scientific papers (Tollefson, 2018). However, this distribution is logical when compared to the size of these countries: the bigger they are, the more they produce. Yet, checking the f-measure leads to a different: countries such as Indonesia or Malaysia show specialisation in the social and environmental fields, indicating their interest in those issues. Regarding environmental research, northern European countries (Finland and Sweden) are at the top of the rankings: these countries also score highly in the Sustainable Development Goals (SDGs) Index. According to the 2018 Ranking, Sweden was in the first place and Finland in the third place (Bertelsmann Stiftung and SDSN, 2018). This suggests that, apart from being involved in SDG practices at different levels, they are specialised and do research on these topics.

As concerns institutions, research on these topics is done primarily at universities, government Departments (e.g., United States Department of Agriculture), and research councils (e.g., Consiglio Nazionale delle Ricerche, CNR). The Chinese Academy of Sciences (China), the Wageningen University Research (Netherlands), and the University of California System (USA) are institutions that often appear in the three pillars. The Wageningen University Research is the top university in the GreenMetrics Ranking (2017 edition), and some in the University of California System (4 of 10 campuses) are present in the ranking. This ranking, developed by Indonesia University, values aspects of sustainability in the universities and shows that these institutions, apart from being proactive regarding sustainability actions, are also researching these topics. These results are in line with those of the studies on renewable energy sources (Romo-Fernández et al., 2012; Sanz-Casado, 2014), where the key producers are universities or research centres. In addition, there is no participation by hospitals and companies in the scientific production: this is indicative of the limited commitment by any other institutional sectors to basic scientific research related to sustainability.

Regarding collaboration patterns, there is a growing trend of international collaborations (23.63\% in environmental, $20.43 \%$ in social, and $18.36 \%$ in economic), as well as national collaborations $(25.97 \%$ in economic, $24.05 \%$ in environmental, and $19.20 \%$ in social), in contrast to documents without collaboration. These results are in line with those of Yarime et al. (2010), who analysed sustainability science and showed that the proportion of articles published through international collaboration is on the rise.

$R Q 2$. What are the main thematic specialisations in these fields?

Taking into consideration the topics of interest, this information has been analysed in two ways: by WoS categories and by the cooccurrence in a keyword network. The WoSindexed journals containing papers on the three pillars of sustainability were most frequently classified under the 'Environmental Sciences', 'Environmental Studies', or 'Green \& Sustainable Science \& Technology' categories. However, the rest of the WoS categories have their specific fields: social sustainability has scientific production in categories related to urban research ('Urban Studies' or 'Planning \& Development'); economic sustainability in 'Business', 'Economics', or 'Management'; and, in the case of 
environmental sustainability, research is concentrated under 'Environmental Engineering' or 'Energy \& Fuels', amongst others.

Given that sustainability is defined as a very ambiguous concept (Walker and Shove, 2007), some terms in cooccurrence network maps are shared amongst the networks. Two common topics are addressed in the three groups:

- $\quad$ performance and management

- $\quad$ sustainable development.

The first can be related to the analysis and assessment of different measures to achieve a sustainable future. This concern is common in the three clusters and is related to industry/business performance (e.g., corporate social responsibility, supply chain management). As stated in Vilches and Gil (2003), those measures to achieve sustainability would be technologies for sustainability and universal governance and are seen as nodes in the cluster. In the second cluster, on sustainable development, some terms cover different topics (e.g., climate change, agriculture, biodiversity). Research in $\mathrm{SD}$ could be related to the fact that it has not been deemed a priority area. In the social sustainability cluster, research is linked to city nodes, denoting interest in urban research (Ramírez Ríos et al., 2016). There is another fact worth mentioning: the network where $\mathrm{SD}$ is linked to the other three pillars (the other nodes), showing the relationship between the three of them in SD research.

$R Q 3$. What are the characteristics of the acknowledgements?

Differences between these three major pillars in the funding data for acknowledgements do exist and constitute relevant information concerning impact and collaboration patterns. The area with the most acknowledgement documents is Environmental Sustainability (33\%), indicating that most of the research done on this topic could be related to research councils, governments or HEIs/Research centres that are providing funding for conducting this research (e.g., European Commission, National Science Foundation of China). Social sustainability is the area with the lowest number of documents with funding acknowledgements. This fact was also observed in Díaz-Faes and Bordons (2014), where the lowest presence of funding information was found in social sciences and humanities (SSH).

Regarding impact, it is higher in documents with funding in the environmental (26.31 citations/document) and social areas (21.81 citations/documents). This is in line with some studies that mentioned that funded research receives higher citation rates (Wang and Shapira, 2015; Álvarez-Bornstein et al., 2019) than research that is not funded. Contrary to other disciplines, such as Cardiology and Virology in Álvarez-Bornstein (2019), funded research was not more likely to appear in high-impact factor journals (higher Q1), indicating less visibility of funded research.

Another fact to be considered is the size of the teams (no. of authors). The results show that funded research was conducted by larger teams, indicating higher collaboration. This higher presence in papers with funding is consistent with previous studies (Costas and van Leeuwen, 2012; Díaz-Faez and Bordons, 2014).

In conclusion, this study helps to understand the research landscape in important, but heterogeneous, of the three main pillars of SD. From this study, it can be inferred that there has been a greater scientific effort in the subject of sustainability in recent years, denoting that the research interest goes in line with a greater societal awareness on this 
topic. This paper tries to shed some light on the matter, providing an overview of research on this field.

A few limitations of this study should be noted. First, we did not conduct a systematic search for all articles about sustainability: we identified primary articles of the three main pillars of sustainability, identifying its 'seed' of publications. On this regard, we might have missed some articles that included other aspects of sustainability. In particular, articles related to other pillars (e.g., institutional) could have been excluded from our study. Future research could build on our work and include other pillars of sustainability and determine the characteristics and relationships among them. Second, regarding FA field it bears mentioning that authors do not always acknowledge funding sources. Nevertheless, this analysis could lead to a general overview of how funding affects scientific papers in this field.

\section{Acknowledgements}

This research has received funding from the European Unions' Horizon 2020 Research and Innovation Program under grant 741657, called SciShops.eu. The content of this article does not reflect the official opinion of the European Union. Responsibility for the information and views expressed in the article lies entirely with the authors. This work was also supported by predoctoral contract BES-2015-075461.

\section{References}

Alshuwaikhat, H.M. and Abubakar, I. (2008) 'An integrated approach to achieving campus sustainability: assessment of the current campus environmental management practices', Journal of Cleaner Production, Vol. 16, No. 16, pp.1777-1785, https://doi.org/10.1016/ j.jclepro.2007.12.002

Álvarez-Bornstein, B., Díaz-Faes, A.A. and Bordons, M. (2019) 'What characterises funded biomedical research? evidence from a basic and a clinical domain', Scientometrics, Vol. 119, No. 2, pp.805-825, https://doi.org/10.1007/s11192-019-03066-3

Amador, F. and Oliveira, C.P. (2013) 'Integrating sustainability into the university: past, present, and future', in Caeiro, S., Filho, W.L., Jabbour, C. and Azeiteiro, U.M. (Eds.): Sustainability Assessment Tools in Higher Education Institutions: Mapping Trends and Good Practices Around the World, Springer International Publishing, Cham, pp.65-78, https://doi.org/10.1007/978-3-319-02375-5_4

Axelsson, R., Angelstam, P., Degerman, E., Teitelbaum, S., Andersson, K., Elbakidze, M. and Drotz, M.K. (2013) 'Social and cultural sustainability: criteria, indicators, verifier variables for measurement and maps for visualization to support planning', AMBIO, Vol. 42, No. 2, pp.215-228, https://doi.org/10.1007/s13280-012-0376-0

Bertelsmann Stiftung, SDSN (Sustainable Development Solutions Network) (2018) SDG Index and Dashboards Report 2018, Global responsibilities: implementing the goals. Retrieved from: http://www.sdgindex.org/assets/files/2018/01\%20SDGS\%20GLOBAL\%20ED.\%20WEB\%20 V8\%20060718.pdf (Accessed 19 September, 2019).

Brown, L. (2006) Plan B 2.0: Rescuing a Planet under Stress and a Civilization in Trouble, W.W. Norton and Co., New York, London.

Brundtland, G. (1987) Our Common Future: Report of the 1987 World Commission on Environment and Development, United Nations, Oslo, Vol. 1, p.59. 
Burns, T.R. (2012) 'The sustainability revolution: a societal paradigm shift', Sustainability, Vol. 4, No. 6, pp.1118-1134, https://doi.org/10.3390/su4061118

Camargo, B.V. and Justo, A.M. (2013) 'IRAMUTEQ: Um software gratuito para análise de dados textuais', Temas Em Psicologia, Vol. 21, No. 2, pp.513-518, https://doi.org/10.9788/ TP2013.2-16

Costas, R. and van Leeuwen, T.N. (2012) 'Approaching the 'reward triangle': general analysis of the presence of funding acknowledgments 'peer interactive communication", in Scientific Publications, Journal of the American Society for Information Science and Technology, Vol. 63, No. 8, pp.1647-1661, https://doi.org/10.1002/asi.22692

Díaz-Faes, A.A. and Bordons, M. (2014) 'Acknowledgments in scientific publications: presence in Spanish science and text patterns across disciplines', Journal of the Association for Information Science and Technology, Vol. 65, No. 9, pp.1834-1849, https://doi.org/ 10.1002/asi.23081

Disterheft, A., Caeiro, S., Azeiteiro, U.M. and Leal Filho, W. (2013) 'Sustainability science and education for sustainable development in universities: a way for transition', Sustainability Assessment Tools in Higher Education Institutions, Springer International Publishing, Cham, https://doi.org/10.1007/978-3-319-02375-5_1, pp.3-27

Dong, B., Xu, G., Luo, X., Cai, Y. and Gao, W. (2012) 'A bibliometric analysis of solar power research from 1991 to 2010', Scientometrics, Vol. 93, No. 3, pp.1101-1117, https://doi.org/ 10.1007/s11192-012-0730-9

Edwards, A.R. (2005) The Sustainability Revolution: Portrait of a Paradigm Shift, New Society Publishers.

Elkington, J. (1998) 'Partnerships from cannibals with forks: the triple bottom line of 21st-century business', Environmental Quality Management, Vol. 8, No. 1, pp.37-51, https://doi.org/ 10.1002/tqem.3310080106

Feng, Y., Zhu, Q. and Lai, K-H. (2017) 'Corporate social responsibility for supply chain management: a literature review and bibliometric analysis', Journal of Cleaner Production, Vol. 158, pp.296-307, https://doi.org/10.1016/j.jclepro.2017.05.018

$\mathrm{Fu}, \mathrm{Y}$. and Zhang, X. (2017) 'Trajectory of urban sustainability concepts: a 35-year bibliometric analysis', Cities, Vol. 60, pp.113-123, https://doi.org/10.1016/j.cities.2016.08.003

Fukuda-Parr, S. (2016) 'From the millennium development goals to the sustainable development goals: shifts in purpose, concept, and politics of global goal setting for development', Gender and Development, Vol. 24, No. 1, pp.43-52, https://doi.org/10.1080/13552074.2016.1145895

Gómez-Caridad, I. and Bordons, M. (1996) 'Limitaciones en el uso de los indicadores bibliométricos para la evaluación científica', Política Científica v, Vol. 46, No. 10, pp.21-26.

Hesselbarth, C. and Schaltegger, S. (2014) 'Educating change agents for sustainability - learnings from the first sustainability management master of business administration', Journal of Cleaner Production, Vol. 62, pp.24-36, https://doi.org/10.1016/j.jclepro.2013.03.042

Holland, A. (2000) 'Introduction-sustainable development: the contested vision', in Lee, K., McNeill, D. and Lee, K. (1938) and Holland, A.J. (Alan John), 1939-2000 (Eds.): Global Sustainable Development in the Twenty-First Century, Edinburgh University Press, Edinburgh.

Kajikawa, Y. (2008) 'Research core and framework of sustainability science', Sustainability Science, Vol. 3, No. 2, pp.215-239, https://doi.org/10.1007/s11625-008-0053-1

Kajikawa, Y., Tacoa, F. and Yamaguchi, K. (2014) 'Sustainability science: the changing landscape of sustainability research', Sustainability Science, Vol. 9, No. 4, pp.431-438, https://doi.org/ 10.1007/s11625-014-0244-x

Kastenhofer, K. and Rammel, C. (2005) 'Obstacles to and potentials of the societal implementation of sustainable development: a comparative analysis of two case studies', Sustainability: Science, Practice and Policy, Vol. 1, No. 2, pp.5-13, https://doi.org/10.1080/ 15487733.2005.11907968 
Kates, R.W., Clark, W.C., Corell, R., Hall, J.M., Jaeger, C.C., Lowe, I., McCarthy, J.J. and Schellnhuber, H.J., Bolin, B., Dickson, N.M., Faucheux, S., Gallopin, G.C., Grübler, A., Huntley, B., Jäger, J., Jodha, N.S., Kasperson, R.E., Mabogunje, A., Matson, P., Mooney, H., Moore III, B., O'Riordan, T. and Svedin, U. (2001) 'Environment and development: sustainability science', Science, Vol. 292, No. 5517, pp.641-642, https://doi.org/10.1126/ science. 1059386

Leal Filho, W. (2000) 'Dealing with misconceptions on the concept of sustainability', International Journal of Sustainability in Higher Education, Vol. 1, No. 1, pp.9-19, https://doi.org/10.1108/ 1467630010307066

Leal Filho, W., Manolas, E. and Pace, P. (2015) 'The future we want', International Journal of Sustainability in Higher Education, Vol. 16, No. 1, pp.112-129, https://doi.org/10.1108/ IJSHE-03-2014-0036

Lozano, R. (2008) 'Envisioning sustainability three-dimensionally', Journal of Cleaner Production, Vol. 16, No. 17, pp.1838-1846, https://doi.org/10.1016/j.jclepro.2008.02.008

Lozano-Ros, R. (2003) Sustainable Development in Higher Education. Incorporation, Assessment and Reporting of Sustainable Development in Higher Education Institutions, MSc thesis in Environmental Management and Policy, IIIEE, Lund University, Lund.

Malthus, T.R. (1798) 'An essay on the principle of population as it affects the future improvement of society, with remarks on the speculations of Mr. Goodwin, M. Condorcet, and other writers', London: Printed for Johnson, J., in St. Paul's Church-yard, Retrieved from: https://archive.org/details/essayonprincipl00malt/page/n7 (Accessed 19 September, 2019).

Martens, P. (2006) 'Sustainability: Science or fiction?', Sustainability: Science, Practice and Policy, Vol. 2, No. 1, pp.36-41, https://doi.org/10.1080/15487733.2006.11907976

Mitcham, C. (1995) 'The concept of sustainable development: its origins and ambivalence', Technology in Society, Vol. 17, No. 3, pp.311-326, https://doi.org/10.1016/0160791X(95)00008-F

Nilsson, P. (2004) NGO Involvement in the UN Conference on the Human Environment in Stockholm 1972, Interrelations Between Intergovernmental Discourse Framing and Activist Influence, Ekonomiska Institutionen, Linköping.

Nučič, M. (2012) 'Is sustainability science becoming more interdisciplinary over time?', Acta Geographica Slovenica, pp.215-236, https://doi.org/10.3986/AGS52109

OHCHR (Office of the High Commissioner on Human Rights) (2008) Claiming the Millennium Development Goals: A Human Rights Approach, UN, New York.

Pulgarín, A., Eklund, P., Garrote, R. and Escalona-Fernández, M.I. (2015) 'Evolution and structure of 'sustainable development': a bibliometric study', Brazilian Journal of Information Science: Research Trends, Vol. 9, No. 1, p.24.

Ramírez Ríos, J.F. and Alzate Ibáñez, A.M. and Montenegro Riaño, D.F. (2016) 'Los Discursos De La Sostenibilidad: Análisis De Tendencias Conceptuales a Partir De Mediciones Bibliométricas', Questionar: Investigación Especifica, Vol. 4, No. 1, pp.82-96, Retrieved from http://hdl.handle.net/20.500.11839/6286 (Accessed 19 September, 2019).

Robinson, J. (2004) 'Squaring the circle? Some thoughts on the idea of sustainable development', Ecological Economics, Vol. 48, No. 4, pp.369-384, https://doi.org/10.1016/j.ecolecon.2003.10.017

Romo-Fernández, L.M., Guerrero-Bote, V.P. and Moya-Anegón, F. (2012) 'World scientific production on renewable energy, sustainability and the environment', Energy for Sustainable Development, Vol. 16, No. 4, pp.500-508, https://doi.org/10.1016/j.esd.2012.06.005

Rousseau, R. (2018) 'The F-measure for research priority', Journal of Data and Information Science, Vol. 3, No. 1, pp.1-18, https://doi.org/10.2478/jdis-2018-0001

Ruhanen, L., Weiler, B., Moyle, B.D. and McLennan, C.J. (2015) 'Trends and patterns in sustainable tourism research: a 25-year bibliometric analysis', Journal of Sustainable Tourism, Vol. 23, No. 4, pp.517-535, https://doi.org/10.1080/09669582.2014.978790 
Sanz-Casado, E., Lascurain-Sánchez, M.L., Serrano-Lopez, A.E., Larsen, B. and Ingwersen, P. (2014) 'Production, consumption and research on solar energy: the Spanish and German case', Renewable Energy, Vol. 68, pp.733-744, https://doi.org/10.1016/j.renene.2014.03.013

Sibbel, A. (2009) 'Pathways towards sustainability through higher education', International Journal of Sustainability in Higher Education, Vol. 10, No. 1, pp.68-82, https://doi.org/10.1108/14676370910925262

Sosik, J.J. (2011) 'Full-range leadership development: pathways for people, profit and planet', Human Resource Management International Digest, Vol. 19, No. 1, hrmid.2011.04419aae. 003, https://doi.org/10.1108/hrmid.2011.04419aae.003

Sosik, J.J. and Jung, D. (2018) Full Range Leadership Development: Pathways for People, Profit, and Planet, Routledge, New York, NY.

Tang, M., Liao, H., Wan, Z., Herrera-Viedma, E. and Rosen, M. (2018) 'Ten years of sustainability (2009 to 2018): a bibliometric overview', Sustainability, Vol. 10, No. 5, p.1655, https://doi. org/10.3390/su10051655

Tollefson, J. (2018) 'China declared largest source of research articles', Nature, Vol. 553, No. 7689, pp.390-390.Retrieved from: https://www.nature.com/magazine-assets/d41586-01800927-4/d41586-018-00927-4.pdf (Accessed 18 September 2019

United Nations (2016) The Sustainable Development Goals Report 2016, Retrieved from: https://unstats.un.org/sdgs/report/2016/The\%20Sustainable\%20Development\%20Goals\%20Re port\%202016.pdf (Accessed 18 September, 2019).

van Eck, N.J. and Waltman, L. (2010) 'Software survey: VOSviewer, a computer program for bibliometric mapping', Scientometrics, Vol. 84, No. 2, pp.523-538, https://doi.org/ 10.1007/s11192-009-0146-3

Vilches, A. and Gil, D. (2003) Construyamos Un Futuro Sostenible. Diálogos De Supervivencia, Cambridge University Press, Madrid.

Waas, T., Verbruggen, A. and Wright, T. (2010) 'University research for sustainable development: definition and characteristics explored', Journal of Cleaner Production, Vol. 18, No. 7, pp.629-636, https://doi.org/10.1016/j.jclepro.2009.09.017

Walker, G. and Shove, E. (2007) 'Ambivalence, sustainability and the governance of socio-technical transitions', Journal of Environmental Policy \& Planning, Vol. 9, Nos. 3-4, pp.213-225, https://doi.org/10.1080/15239080701622840

Wang, J. and Shapira, P. (2015) 'Is there a relationship between research sponsorship and publication impact? An analysis of funding acknowledgments in nanotechnology papers', PLOS ONE, Vol. 10, No. 2, e0117727, https://doi.org/10.1371/journal.pone.0117727

Wiek, A., Farioli, F., Fukushi, K. and Yarime, M. (2012) 'Sustainability science: bridging the gap between science and society', Sustainability Science, Vol. 7, No. S1, pp.1-4, https://doi.org/ 10.1007/s11625-011-0154-0

Wright, T.S.A. (2002) 'Definitions and frameworks for environmental sustainability in higher education', International Journal of Sustainability in Higher Education, Vol. 3, No. 3, pp.203-220, https://doi.org/10.1108/14676370210434679

Yarime, M., Takeda, Y. and Kajikawa, Y. (2010) 'Towards institutional analysis of sustainability science: a quantitative examination of the patterns of research collaboration', Sustainability Science, Vol. 5, No. 1, pp.115-125, https://doi.org/10.1007/s11625-009-0090-4

Zimmerman, J.B. (2005) 'EPA's P.3 - people, prosperity, and planet - award', Science, Practice and Policy, Vol. 1, No. 2, pp.32-33, https://doi.org/10.1080/15487733.2005.11907971. 